Hydrol. Earth Syst. Sci., 17, 2185-2193, 2013

www.hydrol-earth-syst-sci.net/17/2185/2013/

doi:10.5194/hess-17-2185-2013

(c) Author(s) 2013. CC Attribution 3.0 License.

\title{
Assessing the hydrological effect of the check dams in the Loess Plateau, China, by model simulations
}

\author{
Y. D. $\mathbf{X u}^{1,2}$, B. J. Fu ${ }^{1}$, and C. S. He $\mathrm{He}^{3,4}$ \\ ${ }^{1}$ State Key Laboratory of Urban and Regional Ecology, Research Center for Eco-Environmental Sciences, \\ Chinese Academy of Sciences, P.O. Box 2871, Beijing 100085, China \\ ${ }^{2}$ State Environmental Protection Key Laboratory of Regional Ecological Processes and Functions Assessment, \\ Chinese Research Academy of Environmental Sciences, Beijing 100012, China \\ ${ }^{3}$ Center for Dryland Water Resources Research and Watershed Science, Key Laboratory of West China's Environmental \\ System (Ministry of Education), Lanzhou University, Lanzhou 730000, China \\ ${ }^{4}$ Department of Geography, Western Michigan University, Kalamazoo, Michigan 49008-5424, USA
}

Correspondence to: B. J. Fu (bfu@ rcees.ac.cn)

Received: 29 October 2012 - Published in Hydrol. Earth Syst. Sci. Discuss.: 6 December 2012

Revised: 2 April 2013 - Accepted: 8 May 2013 - Published: 10 June 2013

\begin{abstract}
Check dams are commonly used for soil conservation. In the Loess Plateau of China, check dams have been widely constructed as the principal means to retain floodwater and intercept soil sediments since the 1970s. For instance, there are more than 6572 check dams in the Yanhe watershed with an area of $7725 \mathrm{~km}^{2}$ in the Loess Plateau. However, little research has been done to quantify the hydrological effects of the check dams.

In this research, the SWAT model (Soil and Water Assessment Tool) was applied to simulate the runoff and sediment in the Yanhe watershed. We treated the 1950s to 1960s as the reference period since there were very few check dams during the period. The model was firstly calibrated and validated in the reference period. The calibrated model was then used in the later periods to simulate the hydrological effects of the check dams.

The results showed that the check dams had a regulation effect on runoff and a retention effect on sediment. From 1984 to 1987, the runoff in rainy season (from May to October) decreased by $1.54 \mathrm{~m}^{3} \mathrm{~s}^{-1}(14.7 \%)$ to 3.13 $\mathrm{m}^{3} \mathrm{~s}^{-1}(25.9 \%)$ due to the check dams; while in dry season (from November to the following April), runoff increased by $1.46 \mathrm{~m}^{3} \mathrm{~s}^{-1}(60.5 \%)$ to $1.95 \mathrm{~m}^{3} \mathrm{~s}^{-1}(101.2 \%)$; the sediment in rainy season decreased by $2.49 \times 10^{6}$ ton (34.6\%) to $4.35 \times 10^{6}$ ton $(48.0 \%)$. From 2006 to 2008 , the runoff in rainy season decreased by $0.79 \mathrm{~m}^{3} \mathrm{~s}^{-1}(15.5 \%)$ to $1.75 \mathrm{~m}^{3} \mathrm{~s}^{-1}(28.9 \%)$, and the runoff in dry season increased
\end{abstract}

by $0.51 \mathrm{~m}^{3} \mathrm{~s}^{-1}(20.1 \%)$ to $0.97 \mathrm{~m}^{3} \mathrm{~s}^{-1}(46.4 \%)$; the sediment in rainy season decreased by $2.03 \times 10^{6}$ ton $(79.4 \%)$ to $3.12 \times 10^{6}$ ton $(85.5 \%)$.

Construction of the large number of check dams in the Loess Plateau has enhanced the region's capacity to control the runoff and sediment. In the Yanhe watershed, the annual runoff was reduced by less than $14.3 \%$ due to the check dams; and the sediment in rainy season was blocked by up to $85.5 \%$. Thus, check dams are effective measures for soil erosion control in the Loess Plateau.

\section{Introduction}

Check dam is a type of engineering measure for soil conservation in erodible areas. A check dam is composed of an embankment and a spillway. Some simple check dams consist of only embankments. While not common around the world, check dams have been implemented for soil erosion control and reported in some countries, including China, France, Italy, Iran, and Spain.

In the Loess Plateau of China, check dams have been put into effect for hundreds of years for soil erosion control. Especially since the 1970s, many check dams have been constructed in the region. By 2005, there were 122028 check dams in the Loess Plateau (Ministry of Water Resources of the People's Republic of China, 2010), averaging 1 check 


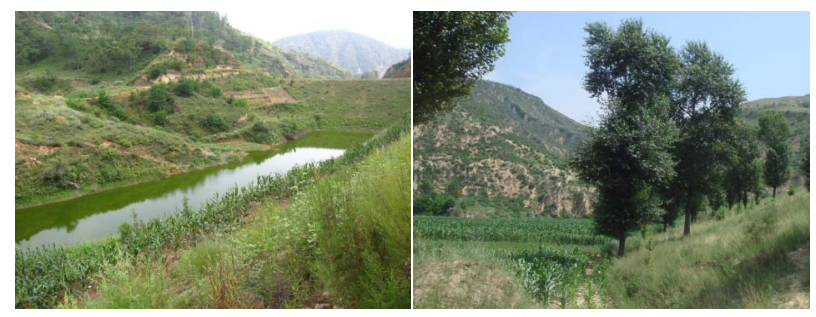

Fig. 1. Sample graphs of check dam (left: water body behind a check dam; right: farmland formed by a check dam) (photo: Yafeng Wang and Yanda $\mathrm{Xu}$ ).

dam per $5 \mathrm{~km}^{2}$, with an even higher density in the middle reaches of the Loess Plateau

Check dams retain floodwater and intercept soil sediments. At the beginning of the construction, a water body would be formed behind the check dam (Fig. 1 left). Gradually, the water body was filled by sediment deposition. The area formed by the deposit is usually used as farmland, which plays an important role in the grain production in the region (Fig. 1 right). Over time, check dams would eventually be filled up.

Research on check dams around the world has focused on their hydrological and geomorphological effects. Bombino et al. (2009) investigated the impact of check dams on channel form, sediment caliber and vegetation in the headwater reaches in Calabria, southern Italy. The results suggested statistically significant differences in channel form, sediment and vegetation development among the upstream, the downstream, and the intermediate sections of check dams. Hassanli et al. (2009) evaluated the effect of porous check dam location on the retention of fine sediments by field sampling and laboratory analysis in the Droodzan watershed, southern Iran. Remaître et al. (2008) used a debris-flow model to evaluate the influence of the number and the location of the check dams on the debris-flow intensity in the Faucon watershed of south French Alps. The results indicated that check dams located near the source area may decrease debris-flow intensity more efficiently.

A series of research on check dams have been engaged in Spain (Boix Fayos et al., 2008; Castillo et al., 2007; Conesa García et al., 2007; Boix Fayos et al., 2007). Based on field observations and modeling analysis, the studies assessed the impact of check dams on channel morphology, channel bed stability and catchment sediment yield. The results show that the check dams hold sediments and cause a decrease in the longitudinal gradient upstream, but accelerate erosion downstream because of the increased flow transport capacity and scour processes; check dams reduce catchment sediment yield, by up to $77 \%$ in the case of the Rogativa catchment (SE Spain). Besides, Martín Rosales et al. (2007) estimated the groundwater recharge induced by check dams and gravel pits. The results showed that the proportion of runoff that infiltrates through the check dams varied from $3 \%$ to more than $50 \%$.
By estimating the sediment retained by check dams in the Yellow River watershed, Xu et al. (2002, 2004) concluded that the check dam system in gullies was one of the most effective soil conservation means in the Loess Plateau, China. In five typical catchments in the Hekou-Longmen section of the midstream of the Yellow River, Ran et al. (2008) analyzed the coarse sediment retention by check dams and found that when the percentage of the basin area above check dams in the catchments reached $3.0 \%$, the average sediment reduction ratio can reach $60 \%$. Moreover, check dams were reported to increase carbon retention in Yan'an prefecture of the Loess Plateau, China (Lü et al., 2012).

Two constraints exist in the current research on check dams. Firstly, mechanisms of the hydrological effect of check dams are unclear. The effect of check dams on flood control and soil retention can only be assessed qualitatively but not quantitatively. The model WATEM-SEDEM was applied to simulate the impact of check dams on sediment transport (Boix Fayos et al., 2008). Check dams were treated as sedimentation areas in the model. However, the model can only simulate the average annual sediment yield but could not judge when the check dams were filled up. The runoff processes in the channels with check dams were difficult to simulate. Secondly, observations of check dams are difficult to obtain. In the Loess Plateau, China, check dams were constructed at the request of the residents without any long-term design schemes. The locations, storage capacities and outflow methods have not been inventoried and documented.

Considering the two constraints, it is hard to quantitatively assess the hydrological impacts of check dams based on the channel flow routing processes in the Loess Plateau. However, simulating the hydrological processes in a watershed without check dams is possible. If the hydrological model was calibrated and validated for the period before check dams were constructed, using the same parameters to simulate the hydrological processes of the watershed with check dams constructed, the difference between the observed hydrological data and simulated ones could be treated as the effect of the check dams.

In this article, the 1950s-1960s were treated as the reference period, when there were few check dams in the study area. A hydrological model (SWAT) was calibrated and validated for the referenced period. The hydrological processes of the study area after the 1970s were simulated by the calibrated SWAT model. Comparing with the observed data, the effect of check dams on runoff and sediment yield were evaluated by the simulated data. Note that there were 5 hydrologic stations in the Yanhe watershed. The comparison between the simulated and observed data of these stations leads to the same conclusion (Xu, 2012). In consideration of the article's length and results' conciseness, the Ganguyi hydrologic station was selected in this article, for it is the the most downstream station and could represent most of the watershed. 


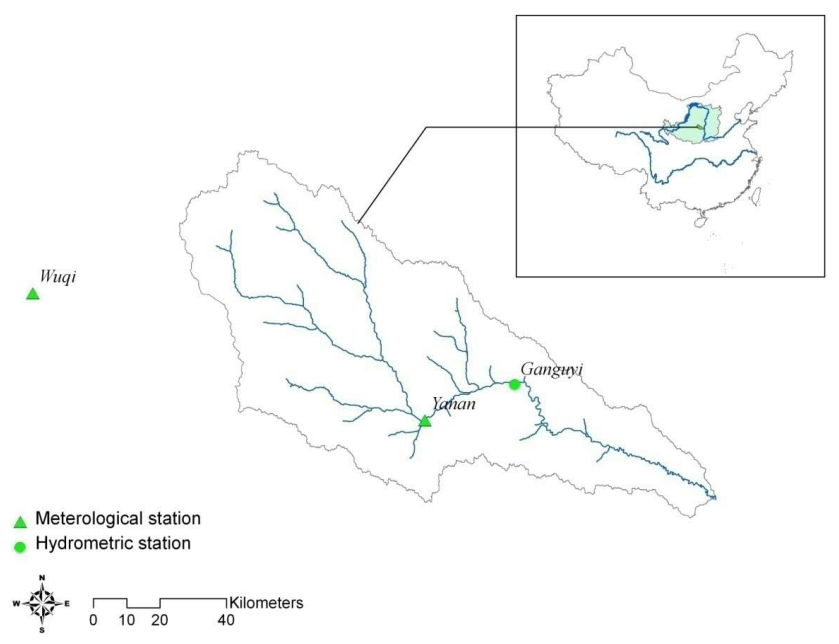

Fig. 2. Study area and the locations of hydrometric station and meteorological stations.

\section{Methods}

\subsection{Study area}

The Yanhe watershed $\left(108^{\circ} 38^{\prime}-110^{\circ} 29^{\prime} \mathrm{E}, \quad 36^{\circ} 21^{\prime}-\right.$ $37^{\circ} 19^{\prime} \mathrm{N}$ ) lies in the middle of the Loess Plateau, China (Fig. 2). The area of the watershed is $7725 \mathrm{~km}^{2}$. The landform is a typical loess hilly/gullied landscape with elevations ranging from 495 to $1795 \mathrm{~m}$ above sea level, with an average elevation of $1218 \mathrm{~m}$. The average slope is $23.4^{\circ}$.

The watershed has a typical semiarid continental climate. The average temperature is $8.8^{\circ} \mathrm{C}$ and the average annual precipitation is $505 \mathrm{~mm}$. Rainfall shows high seasonal variability, with more than $60 \%$ of the annual precipitation occurring between July and September.

The dominant vegetation in the watershed is grassland. The dominant soil, loess soil, is derived from loess parent material. The soil and the parent material are both very erodible (Xu et al., 2012).

The topography, climate, vegetation and soil collectively cause the serious soil erosion in the watershed. The average erosion rate is 8100 ton $\mathrm{km}^{-2} \mathrm{yr}^{-1}$. For conserving soil, re-vegetation and engineering measures have been implemented for decades. The "Grain-for-Green" project launched in 1999 is the largest plantation project, in which many croplands were fallowed or afforested. The engineering measures have been implemented in the region for a quite long period. Check dams are the most common ways in the engineering measures. By the end of 2002, there were 6572 check dams in the Yanhe watershed, counting as 1 check dam per $1.18 \mathrm{~km}^{2}$ (Hui et al., 2002).

\subsection{Datasets}

Databases of topography, land use, soil, meteorology, runoff and sediment were collected from difference sources. Runoff and sediment data were used for model calibration, validation and assessment of the hydrological effects of the check dams.

A 25 m-resolution digital elevation model (DEM) for the Yanhe watershed, derived from a 1:50000 scale contour map, was supplied by the National Geomatics Center of China.

Land use maps for the years 1975, 1990 and 2008 (1: 100000 scale) were interpreted by the Institute of Remote Sensing Applications, Chinese Academy of Sciences, from remotely sensed Landsat images. Six land use types were identified: forest, shrubland, grassland, cropland, water bodies and residential areas.

A soil survey map (1:500 000 scale) by the comprehensive scientific investigation team, Chinese Academy of Sciences, was used in the research. The soil in the watershed was divided into seven types: sandy loess soil, loess soil, grey loess soil, chalk loess soil, dark-purple loess soil, red clay soil and alluvial soil. The soil attributes were obtained from some literature and field works (Xu, 2012; Fu et al., 2005; Guo et al., 1992).

Precipitation, runoff and sediment data of 1956-1960, 1963-1966, 1984-1987, and 2006-2008 were collected. In detail, daily precipitation data of 39 precipitation stations and the monthly flow and sediment yield data of the Ganguyi hydrometric station $\left(109^{\circ} 48^{\prime} \mathrm{E}, 36^{\circ} 42^{\prime} \mathrm{N}\right.$, controlling $76.3 \%$ of the watershed) in the watershed were acquired from "Hydrological Yearbook of the People's Republic of China - Hydrological Data of the Yellow River Basin" published by the Yellow River Water Conservancy Committee.

Meteorological data (daily precipitation, maximum and minimum temperatures, average wind speeds and relative humidity) of 1954 to 2008 were obtained for the Yan'an $\left(109^{\circ} 30^{\prime} \mathrm{E}, 36^{\circ} 36^{\prime} \mathrm{N}\right)$ and Wuqi $\left(108^{\circ} 10^{\prime} \mathrm{E}, 36^{\circ} 55^{\prime} \mathrm{N}\right)$ meteorological stations from China Meteorological Data Sharing Service System (http://new-cdc.cma.gov.cn).

\subsection{Methods}

\subsubsection{Hydrological simulation in the reference period}

The Soil and Water Assessment Tool (SWAT) (Arnold et al., 1998) was applied for hydrological simulation of the Yanhe watershed in this study. It is a watershed-scale model for simulating long-term runoff and nutrient losses from rural watersheds. In the hydrology module of SWAT, rainfall-runoff processes are simulated by either the NRCS curve number (CN) method or the Green \& Ampt infiltration method. As the latter requires sub-daily precipitation data, its application was limited by the availability of precipitation data in the study watershed. In the soil erosion module, the Modified Universal Soil Loss Equation (MUSLE) is applied, in which the sediment yield is a function of runoff factor, soil erodibility factor, cover and management factor, support practice factor, topographic factor and coarse fragment factor. 
Table 1. Parameter sensitivity analysis results.

\begin{tabular}{llrr}
\hline Parameter name & Description & $\begin{array}{r}\text { Rank for } \\
\text { runoff } \\
\text { simulation }\end{array}$ & $\begin{array}{r}\text { Rank for } \\
\text { sediment } \\
\text { simulation }\end{array}$ \\
\hline CN2 & Initial NRCS CN II value & 1 & 1 \\
ESCO & Soil evaporation compensation factor & 2 & 2 \\
ALPHA_BF & Baseflow alpha factor (days) & 3 & 3 \\
SOL_AWC & Available water capacity $\left(\mathrm{mm} \mathrm{H}_{2} \mathrm{O} \mathrm{mm}^{-1}\right.$ soil) & 4 & 5 \\
SOL_K & Saturated hydraulic conductivity $\left(\mathrm{mm} \mathrm{h}^{1-}\right)$ & 5 & - \\
SOL_Z & Soil depth (mm) & 6 & 6 \\
SLSUBBSN & Average slope length (m) & 7 & 7 \\
USLE_P & USLE support practice factor & - & 4 \\
\hline
\end{tabular}

The years 1956-1960 and 1963-1966 were treated as the reference periods, during which there were few check dams in the studied area. Using the DEM, the soil map, the land use map of the year 1975 and the meteorological data between 1954 and 1966, SWAT model was run to simulate the monthly flow and sediment yield from 1956 to 1966 . The simulation period was divided into three parts: the warm-up period (1954-1955), the calibration period (1956-1960) and the validation period (1963-1966). In the calibration, parameter sensitivity was tested by using ArcSWAT. The sensitive parameters were calibrated by the SWAT Calibration and Uncertainty Programs Version 2 (SWAT-CUP2). The calibrated parameters were used in the validation period. Once validated, the parameters would be applied in the simulation of 1984-1987 and 2006-2008.

The agreement between the simulated and observed flow and sediment yield was quantitatively evaluated using the coefficient of determination $\left(R^{2}\right)$ and the Nash-Sutcliffe coefficient $\left(E_{\mathrm{NS}}\right)$ (Nash and Sutcliffe, 1970):

$R^{2}=\frac{\left[\sum_{i}\left(O_{i}-\bar{O}\right)\left(S_{i}-\bar{S}\right)\right]^{2}}{\sum_{i}\left(O_{i}-\bar{O}\right)^{2} \sum_{i}\left(S_{i}-\bar{S}\right)^{2}} \ldots$

$E_{\mathrm{NS}}=1-\frac{\sum_{i}(O-S)_{i}^{2}}{\sum_{i}\left(O_{i}-\bar{O}\right)^{2}} \ldots$

where $O$ is the observed value and $S$ the simulated value, and the overbar means the average value of the variable underneath.

Generally, if $R^{2}>0.6$ and $E_{\mathrm{NS}}>0.5$, the simulation results were regarded as credible.

\subsubsection{Hydrological effects assessment of the check dams}

Once the model was satisfactorily validated, it could be regarded as suitable for the watershed without check dams. The model would be applied for the period after the construction of check dams. There would be a difference between the simulated and observed data. This difference was assessed as the effect of the check dams:

$E=\bar{O}-\bar{S} \ldots$

$\mathrm{EP}=(\bar{O}-\bar{S}) / \bar{S} \cdot 100 \% \ldots$

where $E$ is the hydrological effect of the check dams expressed as absolute number, EP the hydrological effect of the check dams expressed as percentage, $O$ the observed flow or sediment yield value, $S$ the simulated flow or sediment yield value, and the overbar means the average value of the variable underneath.

For the years 1984-1988 and 2006-2008, land use maps of 1990 and 2008 were used instead, respectively.

\section{Results}

\subsection{Simulation results in the reference period}

In the calibration period, parameter sensitivity was analyzed by ArcSWAT. The ranked sensitive parameters are listed in Table 1.

The sensitive parameters were calibrated using the Sequential Uncertainty Fitting (SUFI2) in SWAT-CUP2. In addition, another important parameter USLE_K (USLE soil erodibility factor) was added, for its sensitivity cannot be tested by ArcSWAT. SWAT-CUP2 was run repeatedly until the simulated results were acceptable. The adjustment ranges of the parameters were narrowed during calibration. The final adjustment ranges and the best adjustment values are listed in Table 2. The modeling efficiencies are listed in Table 3, and the simulation results are shown in Fig. 3. Because the parameters gained by SWAT-CUP2 were ranges of numbers, the simulation results were composed of the best simulated values, the lower values of $95 \%$ prediction uncertainty and the upper values of $95 \%$ prediction uncertainty. The $95 \%$ prediction uncertainty (95 PPU) was calculated at the 2.5 and 97.5\% levels of the cumulative distribution of an output variable obtained through Latin hypercube sampling. 

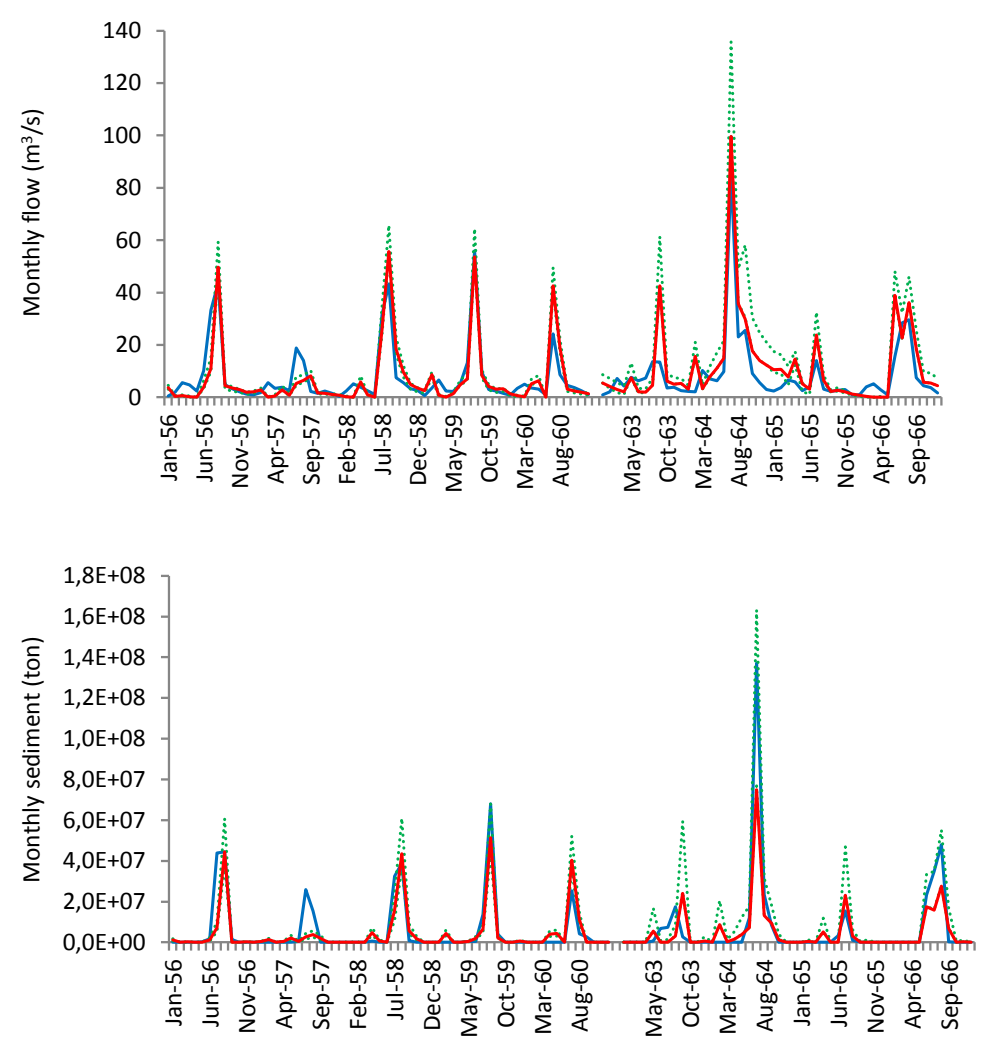

- Observed value ……....95\% prediction uncertainty _- Best simulated value

Fig. 3. Simulation results in the reference period.

In the validation period (1963-1966), the adjustment ranges of the parameters remained unchanged. The results of runoff and sediment simulation were both acceptable (Table 3), which are illustrated in Fig. 3.

\subsection{Simulation results in $1980 \mathrm{~s}$ and $2000 \mathrm{~s}$}

After calibration and validation, SWAT was proved to be applicable in the study area. Using ArcSWAT and SWATCUP2, the calibrated model was applied to simulate the hydrological processes in the 1980s (1984-1987) and 2000s (2006-2008).

However, the simulation results looked apparently unreasonable (Fig. 4), and the modeling efficiencies decreased obviously in the two periods (Table 4). In the former period, the simulated runoff and sediment results kept similar trends with the observation ( $R^{2}$ was more than or near 0.6$)$, but a large bias existed between them $\left(E_{\mathrm{NS}}<0.5\right)$, while in the latter period, even the similar trends vanished.

In the two periods, a similar phenomenon existed in the runoff simulation results. From July to September, most of the simulated values were higher than the observed ones; while from February to April, the simulated values were lower than the observed ones. Therefore, the results were analyzed separately for the rainy season and dry season. In the study watershed, the months from May to October belonged to the rainy season, whose precipitation accounted for $86.8 \%$ of the annual precipitation. The other months composed the dry season (the mean observed and simulated values are listed in Table 5).

\subsection{Hydrological effects of the check dams}

During the simulation in 1984-1987 and 2006-2008, the land use data and meteorological data for the corresponding period were applied. Thus the hydrological impacts of the climate and land use change were excluded. The differences between the observed and simulated values calculated by Eqs. 3 and 4 were treated as the effect of the check dams. With the results in Table 5, the following inferences could be made:

1. In the rainy season, runoff had decreased because of the existence of the check dams, by about $1.54 \mathrm{~m}^{3} \mathrm{~s}^{-1}$ (14.7\%) to $3.13 \mathrm{~m}^{3} \mathrm{~s}^{-1}(25.9 \%)(1984-1987)$ and 15.5 to $28.9 \%$ (2006-2008), respectively. 
Table 2. Results of parameters calibration.

\begin{tabular}{|c|c|c|c|c|}
\hline \multirow{2}{*}{ Parameter } & \multirow{2}{*}{ Type of parameter alteration ${ }^{a}$} & \multicolumn{2}{|c|}{ Adjustment range } & \multirow{2}{*}{ Best adjustment value } \\
\hline & & Lower limit & Upper limit & \\
\hline $\mathrm{CN} 2$ & $r$ & 0.070 & 0.149 & 0.115 \\
\hline ESCO & $v$ & 0.736 & 0.805 & 0.743 \\
\hline ALPHA_BF & $v$ & 0.022 & 0.066 & 0.023 \\
\hline SOL_AWC__-_SLS ${ }^{b}$ & $r$ & -0.018 & 0.064 & -0.010 \\
\hline SOL_K___SLS & $r$ & -0.188 & -0.139 & -0.154 \\
\hline SOL_Z _ & $r$ & 0.008 & 0.141 & 0.066 \\
\hline USLE_K____SLS & $r$ & -0.717 & -0.629 & -0.644 \\
\hline SOL_AWC___LSUP & $r$ & 0.319 & 0.484 & 0.358 \\
\hline SOL_K__LSUP & $r$ & -0.187 & -0.085 & -0.102 \\
\hline SOL Z & $r$ & 0.070 & 0.106 & 0.097 \\
\hline USLE_K___LSUP & $r$ & -0.543 & -0.305 & -0.440 \\
\hline SOL_AWC__LS & $r$ & -0.039 & 0.005 & -0.003 \\
\hline SOL_K__-_LS & $r$ & -0.043 & 0.055 & -0.033 \\
\hline SOL_Z___LS & $r$ & 0.126 & 0.182 & 0.132 \\
\hline USLE_K___LS & $r$ & 0.063 & 0.343 & 0.259 \\
\hline SOL_AWC___GLS & $r$ & -0.079 & 0.040 & -0.028 \\
\hline SOL_K_-_-GLS & $r$ & -0.006 & 0.107 & 0.103 \\
\hline SOL_Z_--_GLS & $r$ & -0.503 & -0.220 & -0.475 \\
\hline USLE_K_-__GLS & $r$ & -0.387 & -0.268 & -0.352 \\
\hline SLSUBBSN & $r$ & 0.575 & 0.844 & 0.709 \\
\hline USLE_P & $v$ & 0.329 & 0.435 & 0.417 \\
\hline
\end{tabular}

Table 3. The modeling efficiencies of the reference period (19561966).

\begin{tabular}{llcc}
\hline Period & Variable & $R^{2 \mathrm{a}}$ & $E_{\mathrm{NS}}^{\mathrm{b}}$ \\
\hline \multirow{2}{*}{ Calibration period (1956-1960) } & Runoff & 0.81 & 0.76 \\
& Sediment yield & 0.73 & 0.72 \\
\hline \multirow{2}{*}{ Validation period (1963-1966) } & Runoff & 0.83 & 0.63 \\
& Sediment yield & 0.87 & 0.73 \\
\hline
\end{tabular}

${ }^{\mathrm{a}} R^{2}-$ the coefficient of determination. ${ }^{\mathrm{b}} E_{\mathrm{NS}}-$ the Nash-Sutcliffe coefficient.

2. In the dry season, runoff had increased by $1.46 \mathrm{~m}^{3} \mathrm{~s}^{-1}$ $(60.5 \%)$ to $1.95 \mathrm{~m}^{3} \mathrm{~s}^{-1}(101.2 \%)(1984-1987)$ and $0.51 \mathrm{~m}^{3} \mathrm{~s}^{-1}(20.1 \%)$ to $0.97 \mathrm{~m}^{3} \mathrm{~s}^{-1}(46.4 \%)$ (20062008), respectively.

3. Annually, the check dams tended to decrease the runoff by up to $0.83 \mathrm{~m}^{3} \mathrm{~s}^{-1}(11.5 \%)(1984-1987)$ and $0.62 \mathrm{~m}^{3} \mathrm{~s}^{-1}(14.3 \%)$ (2006-2008), respectively.

4. During the dry season, sediment transported with water was rarely observed; thus the impact of the check dams on sediment could only be assessed in the rainy season. The simulations show that the check dams reduced the sediment in the rainy season by $2.49 \times 10^{6}$ ton $(34.6 \%)$ to $4.35 \times 10^{6}$ ton $(48.0 \%)(1984-1987)$ and
Table 4. The modeling efficiencies of 1984-1987 and 2006-2008.

\begin{tabular}{clcr}
\hline Period & Variable & $R^{2}$ & \multicolumn{1}{c}{$E_{\mathrm{NS}}$} \\
\hline \multirow{2}{*}{$1984-1987$} & Runoff & 0.74 & -0.21 \\
& Sediment yield & 0.58 & 0.12 \\
\hline \multirow{2}{*}{$2006-2008$} & Runoff & 0.39 & -2.23 \\
& Sediment yield & 0.14 & -27.62 \\
\hline
\end{tabular}

$2.03 \times 10^{6}$ ton $(79.4 \%)$ to $3.12 \times 10^{6}$ ton $(85.5 \%)$ (2006-2008), respectively.

\section{Discussion}

Equifinality (non-uniqueness) is an inherent problem in hydrological modeling research (Bárdossy, 2007). It means a model can obtain the same solutions with different parameter sets. In this research, the warmup-calibration-validation procedures were followed; thus the parameter set had been tested in several periods. The automatic calibration software SWAT-CUP2 was applied to gain calibrated ranges of parameters rather than specific values; most parameters in calibration had physical meanings and had been verified by the field-investigated values. All of the above avoided equifinality to a great degree. Moreover, if equifinality did exist in the 

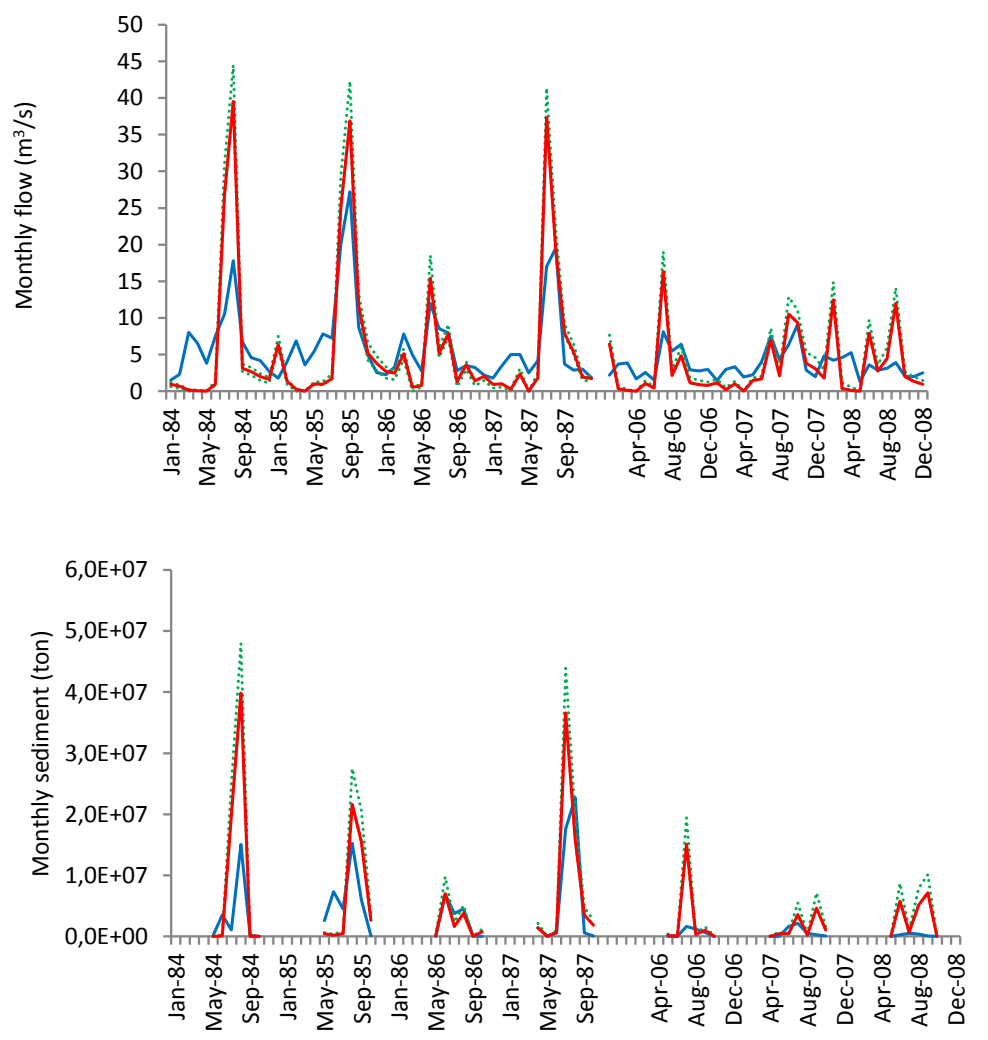

- Observed value .............95\% prediction uncertainty _- Best simulated value

Fig. 4. Simulation results in 1980 s and 2000s.

Table 5. The mean observed and simulated values of 1984-1987 and 2006-2008.

\begin{tabular}{|c|c|c|c|c|c|}
\hline Period & & & Observation & Simulation range & Bias (Eq. 4) \\
\hline \multirow{4}{*}{ 1984-1987 } & \multirow{3}{*}{ Monthly runoff $\left(\mathrm{m}^{3} \mathrm{~s}^{-1}\right)$} & Mean value & 6.42 & $6.21-7.25$ & $-11.5-3.3 \%$ \\
\hline & & Mean value in rainy season & 8.95 & $10.49-12.08$ & $-25.9--14.7 \%$ \\
\hline & & Mean value in dry season & 3.88 & $1.93-2.42$ & $60.5-101.2 \%$ \\
\hline & Monthly sediment (ton) & Mean value in rainy season & $4.71 \times 10^{6}$ & $7.20 \times 10^{6}-9.06 \times 10^{6}$ & $-48.0--34.6 \%$ \\
\hline \multirow{4}{*}{ 2006-2008 } & \multirow{3}{*}{ Monthly runoff $\left(\mathrm{m}^{3} \mathrm{~s}^{-1}\right)$} & Mean value & 3.69 & $3.60-4.31$ & $-14.3-2.6 \%$ \\
\hline & & Mean value in rainy season & 4.31 & $5.10-6.06$ & $-28.9--15.5 \%$ \\
\hline & & Mean value in dry season & 3.07 & $2.10-2.56$ & $20.1-46.4 \%$ \\
\hline & Monthly sediment (ton) & Mean value in rainy season & $5.29 \times 10^{5}$ & $2.56 \times 10^{6}-3.65 \times 10^{6}$ & $-85.5--79.4 \%$ \\
\hline
\end{tabular}

simulation, it could be inferred that the model could obtain correct simulation results in 1980s and 2000s with certain parameter sets. However, after altering the adjustment ranges of parameters and running SWAT-CUP2 repeatedly, the parameter sets were unfound. It is also evidence for the reliability of model prediction. While no field data were available to verify the effects of different parameter sets, multiple simulations in five locations in the Yanhe watershed produced similar results $(\mathrm{Xu}, 2012)$, indirectly indicating that the chosen parameter sets were indeed applicable in the study area.
The simulations showed that the check dams increased the runoff in the dry season. It could be due to the enhanced lateral flow and return flow, which were the main components of the runoff in the dry season. As mentioned previously, the check dams intercept surface runoff and may even lead to the formation of water bodies. This function promoted the infiltration in the soil profile and recharged the groundwater (Callow and Smettem, 2009). Thereby the lateral subsurface flow and the groundwater return flow were enhanced. 
In the rainy season, the surface runoff, which was dominant in the total runoff, was largely intercepted by the check dams. Therefore, the runoff in the rainy season decreased. However, the reduced proportion was not as high as expected (less than $30 \%$ ). It could be attributable to the fact that a portion of surface runoff became subsurface lateral flow and return flow, which entered the channels downstream.

Overall, the annual runoff was reduced by the check dams. The reason may be that the existence of the check dams lead to the increase of evaporation and soil water storage (Wittenberg, 2003).

Lateral and groundwater flow did not contribute significantly to sediment yields (Arnold et al., 1998; Callow and Smettem, 2009). As a result, the sediment that was transported mainly by surface runoff in the rainy season declined significantly.

The hydrological effect of the check dams was different between the two simulation periods. The total runoff, the runoff and the sediment in the rainy season decreased more in the period of 2006-2008 than in the period of 1984-1987. It could be due to the increased check dams, which were constructed continuously between the two periods.

However, the runoff in the dry season was simulated to have increased more in the period of 1984-1987 than in the period of 2006-2008 because of the check dams. It could be explained like this: numerous check dams encouraged the lateral flow and return flow; however, if the check dams kept increasing, the flow emerging into the channels would be obstructed by the downstream check dams. In other words, there was a threshold of the check dams' amount, before which the lateral flow and return flow increased, and after which decreased.

Due to the lack of sediment data, the impact of check dams on the sediment in the dry season was not specifically assessed. It could be inferred that the sediment amount in the dry season would not increase a lot, because the runoff in the dry season was dominant by lateral flow and return flow, which had smaller kinetic energy to detach soil particles (Arnold et al., 1998).

In summary, the check dams reduced the total runoff, regulated runoff in both rainy and dry seasons and decreased sediment yields. Due to the check dams, total runoff decreased by less than $14.3 \%$; meanwhile, sediment yields decreased up to $85.5 \%$. The construction of check dams was an effective measure for soil erosion control in the studied watershed.

If the amount of the check dams keeps increasing, it is likely that the sediment yield will decline; however, it is unclear how the runoff will change. It is crucial to probe into the mechanism of the hydrological processes with check dams and determine appropriate scales for check dam construction.

In addition, the observed annual precipitation and runoff depth in each period were averaged and are shown in Table 6. The runoff coefficients (runoff depth/precipitation) were calculated. This led to a result that the runoff coefficients declined from 1950s and 1960s to 1980s and 2000s. Especially
Table 6. Annual precipitation, runoff depth and runoff coefficient in different periods.

\begin{tabular}{crrr}
\hline & $\begin{array}{r}\text { Annual } \\
\text { precipitation } \\
(\mathrm{mm})\end{array}$ & $\begin{array}{r}\text { Annual } \\
\text { runoff } \\
\text { depth }(\mathrm{mm})\end{array}$ & $\begin{array}{r}\text { Runoff } \\
\text { coefficient }\end{array}$ \\
\hline $1956-1960$ & 526.6 & 38.7 & 0.073 \\
$1963-1966$ & 586.2 & 45.7 & 0.078 \\
$1984-1987$ & 503.6 & 34.5 & 0.069 \\
$2006-2008$ & 539.0 & 19.8 & 0.037 \\
\hline
\end{tabular}

in 2006-2008, the runoff coefficient was less than half of the ones in the two earliest periods. This result further buttressed the conclusion of the check dams' effect.

\section{Conclusions}

The SWAT model, after calibration and validation, was used to simulate the hydrological processes of the Yanhe watershed. For the periods when a large number of check dams had been constructed, the differences between the observations and simulated values were used to assess the hydrological effects of check dams.

The check dams had a regulation function for runoff. In the rainy season (from May to October), the runoff of the Yanhe watershed had decreased by $1.54 \mathrm{~m}^{3} \mathrm{~s}^{-1}(14.7 \%)$ to $3.13 \mathrm{~m}^{3} \mathrm{~s}^{-1}(25.9 \%)(1984-1987)$ and $0.79 \mathrm{~m}^{3} \mathrm{~s}^{-1}(15.5 \%)$ to $1.75 \mathrm{~m}^{3} \mathrm{~s}^{-1}(28.9 \%)(2006-2008)$ respectively due to the check dams. In the dry season (from November to the next April), the runoff rate increased by $1.46 \mathrm{~m}^{3} \mathrm{~s}^{-1}(60.5 \%)$ to $1.95 \mathrm{~m}^{3} \mathrm{~s}^{-1}(101.2 \%)(1984-1987)$ and $0.51 \mathrm{~m}^{3} \mathrm{~s}^{-1}$ (20.1\%) to $0.97 \mathrm{~m}^{3} \mathrm{~s}^{-1}$ (46.4\%) (2006-2008), respectively. The check dams tended to decrease the annual runoff by up to $0.83 \mathrm{~m}^{3} \mathrm{~s}^{-1}(11.5 \%)(1984-1987)$ and $0.62 \mathrm{~m}^{3} \mathrm{~s}^{-1}(14.3 \%)$ (2006-2008), respectively.

The check dams lead to a decrease of the sediment in the rainy season, by a range of $2.49 \times 10^{6}$ ton $(34.6 \%)$ to $4.35 \times 10^{6}$ ton $(48.0 \%)(1984-1987)$ and $2.03 \times 10^{6}$ ton $(79.4 \%)$ to $3.12 \times 10^{6}$ ton $(85.5 \%)(2006-$ 2008), respectively.

The check dam system intercepted up to $85.5 \%$ of the sediment while reducing the runoff by less than $14.3 \%$. It has been proven to be an effective measure for soil erosion control in the Loess Plateau, China. This study only simulated the hydrological effects of the check dams in the study watershed. For a thorough assessment of the impacts of the check dams, a detailed survey of the amounts, locations and characteristics of the check dams is needed, though it is a difficult task in the Loess Plateau, China. 
Acknowledgements. This research was financially supported by the National Natural Science Foundation of China (Grant No. 40930528) and the CAS/SAFEA International Partnership Program for Creative Research Teams of "Ecosystem Processes and Services".

Edited by: J. Liu

\section{References}

Arnold, J. G., Srinivasan, R., Muttiah, R. S., and Williams, J.: Large area hydrologic modeling and assessment part I: Model development, J. Am. Water Resour. As., 34, 73-89, 1998.

Bádossy, A.: Calibration of hydrological model parameters for ungauged catchments, Hydrol. Earth Syst. Sci., 11, 703-710, doi:10.5194/hess-11-703-2007, 2007.

Boix Fayos, C., Barberá, G., López Bermúdez, F., and Castillo, V.: Effects of check dams, reforestation and land-use changes on river channel morphology: Case study of the Rogativa catchment (Murcia, Spain), Geomorphology, 91, 103-123, 2007.

Boix Fayos, C., de Vente, J., Martínez Mena, M., Barberá, G. G., and Castillo, V.: The impact of land use change and check-dams on catchment sediment yield, Hydrol. Process., 22, 4922-4935, 2008.

Bombino, G., Gurnell, A. M., Tamburino, V., Zema, D. A., and Zimbone, S. M.: Adjustments in channel form, sediment calibre and vegetation around check-dams in the headwater reaches of mountain torrents,Calabria, Italy, Earth Surf. Proc. Land., 34, 1011-1021, 2009.

Callow, J., and Smettem, K.: The effect of farm dams and constructed banks on hydrologic connectivity and runoff estimation in agricultural landscapes, Environ. Modell. Softw., 24, 959-968, 2009.

Castillo, V., Mosch, W., Garcia, C. C., Barberá, G., Cano, J., and López-Bermúdez, F.: Effectiveness and geomorphological impacts of check dams for soil erosion control in a semiarid Mediterranean catchment: El Cárcavo (Murcia, Spain), Catena, 70, 416-427, 2007.

Conesa García, C., López Bermúdez, F., and García Lorenzo, R.: Bed stability variations after check dam construction in torrential channels (South-East Spain), Earth Surf. Proc. Land, 32, 21652184, 2007.

Fu, B., Zhao, W., Chen, L., Zhang, Q., Lü, Y., Gulinck, H., and Poesen, J.: Assessment of soil erosion at large watershed scale using RUSLE and GIS: a case study in the Loess Plateau of China, Land Degrad. Develop., 16, 73-85, 2005.

Guo, Z. Y., Huang, Z. L., and Feng, L. X.: Shaanxi Soil, Science Press, Beijing, 1992.
Hassanli, A. M., Nameghi, A. E., and Beecham, S.: Evaluation of the effect of porous check dam location on fine sediment retention (a case study), Environ. Monit. Assess., 152, 319-326, 2009.

Hui, Y. Y., Ji, W. H., and Liu, T. H.: Study on the variation and trend of the runoff and sediment in the Yanhe watershed, in: Study on the variation of the runoff and sediment in the Yellow River watershed (Volume 1) (in Chinese), edited by: Wang, G. and Fan, Z., Yellow River Water Conservancy Press, Zhengzhou, 717-736, 2002.

Lü, Y., Sun, R., Fu, B., and Wang, Y.: Carbon retention by check dams: Regional scale estimation, Ecol. Eng., 44, 139-146, 2012.

Martín Rosales, W., Gisbert, J., Pulido-Bosch, A., Vallejos, A., and Fernández Cortés, A.: Estimating groundwater recharge induced by engineering systems in a semiarid area (southeastern Spain), Environ. Geol., 52, 985-995, 2007.

Ministry of Water Resources of the People's Republic of China, Chinese Academy of Sciences, and Chinese Academy of Engineering: Soil erosion prevetion and ecological safety in China, The volume for the Loess Plateau (in Chinese), Science Press, Beijing, 2010.

Nash, J., and Sutcliffe, J.: River flow forecasting through conceptual models part I - A discussion of principles, J. Hydrol., 10, 282290, 1970.

Ran, D. C., Luo, Q. H., Zhou, Z. H., Wang, G. Q., and Zhang, X. H.: Sediment retention by check dams in the Hekouzhen-Longmen Section of the Yellow River, Int. J. Sediment. Res., 23, 159-166, 2008.

Remaître, A., van Asch, Th. W. J., Malet, J.-P., and Maquaire, O.: Influence of check dams on debris-flow run-out intensity, Nat. Hazards Earth Syst. Sci., 8, 1403-1416, doi:10.5194/nhess-81403-2008, 2008.

Wittenberg, H.: Effects of season and man-made changes on baseflow and flow recession: case studies, Hydrol. Process., 17, 2113-2123, 2003.

Xu, X., Zhang, H., Feng, S., Dong, Z., and Gan, Z.: Check-dam system in gullies - the most effective measure to conserve soil and water in Chinese Loess Plateau, 12th ISCO Conference, Beijing, 2002.

Xu., X., Zhang., H., and Zhang., O.: Development of check-dam systems in gullies on the Loess Plateau, China, Environ. Sci. Policy, 7, 79-86, 2004.

Xu, Y. D.: Modeling research on the spatial and temporal heterogeneity of the eco-hydrological processes in the Yanhe watershed (PhD thesis), Chinese Academy of Sciences, Beijing, 2012.

Xu, Y. D., Fu, B. J., He, C. S., and Gao, G. Y.: Watershed discretization based on multiple factors and its application in the Chinese Loess Plateau, Hydrol. Earth Syst. Sci., 16, 59-68, doi:10.5194/hess-16-59-2012, 2012. 